\title{
Internal Locus of Control and Self -Concept as Factors Affecting the Career Maturity of High School Students
}

\author{
Munawir $^{1^{*}}$, A. Muri Yusuf ${ }^{1}$, Z. Mawardi Effendi ${ }^{1}$, Afdal $^{1}$ \\ ${ }^{1}$ Universitas Negeri Padang, Padang Indonesia \\ *Corresponding author, e-mail: ustnawir@gmail.com
}

\begin{abstract}
Determining the choice of jobs or education choices is one of the tasks during the development of the senior high school. For that, high school students are required to understand and master the concepts of career maturity to be able to pick and choose the appropriate career direction. Career maturity is influenced by several factors, including internal locus of control and self-concept. Someone who has an internal locus of control has a perception that the measures themselves would produce a positive thing that makes their work more successful. The self-concept is considered critical to the success of life because when someone feels good about himself and his ability, to predict a person's life will be successful.
\end{abstract}

Keywords: Career Maturity, Internal Locus of Control, Self-Concept.

How to Cite: Munawir, M., Yusuf, A. M., Effendi, Z. M., \& Afdal, A. (2018). Internal Locus of Control and Self-Concept as Factors Affecting the Career Maturity of High School Students. International Journal of Research in Counseling and Education, 2(1), 24-31. https://doi.org/10.24036/0018za0002

\section{Introduction}

The Senior high school period marked by several important characteristics, such as making choices and prepare for careers match their interests and abilities (Desmita 2011; Prasasti and Laksmiwati, 2017; Rogers and Creed, 2011). It is a requirement that must be met by high school students in the community (Agustiani, 2006). High school students are faced with the choice to go to college or work after graduating (Lawer, 2015; Syakir et al., 2016; Walgito, 2010). This decision is something very big and important to their lives (Atli, 2016; Bardick 2006; Coertse and Schepers, 2004; Novakovic and Fouad, 2012; Usinger and Smith, 2010).

The fact that there are students who have completed high school education could not determine the direction of career planning (Ting et al., 2012). The data shows $90 \%$ of high school students in Bandung is still confusion in the choice of career (Atmaja, 2014). Similarly, SMA 1 Paguyangan Brebes in Central Java Province showed only $10 \%$ of students who have a career maturity in the high category (Athiyah et al., 2014).

As a result of this phenomenon is a quarter of the young generation in Indonesia working in jobs that do not correspond with skill, so do not use themselves with the optimal skills and even worse the younger generation of unemployed (ILO, 2011; Widyastuti and Widyowati, 2015). Most unemployment in Indonesia are high school graduates (Shakir et al., 2016), it was reaffirmed by Section Chief Labor Exchange Muji Wiyono that in the first half of 2017 the unemployment rate amounted to 7.03 million consisting mostly of high school graduates (Krjogja.com, 2017).

Hidayati (2016) also explained that students who study in college as much as $82 \%$ choose majors not based on the selection and career preparation in high school. Some students also expressed their major's elections take only based in order to study at universities without considering the potential and opportunities that are owned. Data show in 2010 about 50\% of students in Canada failed to finish his term of 5 years, is caused by students who switch majors by reason of their majors themselves are not as expected then looked at the other majors is more interesting (Gaylor and Nicol, 2016).

Individuals who are not ready and is not appropriate in the career election caused by the low career maturity (Atli, 2017). Unpreparedness and improper phenomenon in the selection of high school students experienced career beckon them to have a career maturity in order to choose and determine the direction of his career precisely because career maturity is important in selecting careers (Coertse and Schepers, 2004). 
More specifically, the basic skills in the process of selecting a healthy career are when an individual has a career maturity (Atli, 2016; Atli, 2017). Therefore, to understand and master the concepts of career maturity is a requirement for high school students (Leksana, 2015). Essentially are individuals who have a high level of career maturity will have a healthy career choice and had a career confusion in the selection of a lower (Atli, 2016).

Career maturity is the readiness of the individual to complete the task of career development at every stage of career development (Coertse and Schepers, 2004; Dodd et al., 2014; Janeiro, 2010). Super divide stage career development into five stages, namely the growth stage (ages 0-14 years), an exploration stage (age 14-24 years), stage of formation (age 24-44 years), the maintenance phase (ages 44-64 years), and the reduction stage (age 65 until death) (Gladding, 2012; Sterner, 2012). Adolescence can be categorized as the exploratory stage, so that career maturity in adolescence is defined as how well people make a career choice and level of knowledge about education and job selection (Coertse and Schepers, 2004).

Career maturity is influenced by several factors, among others locus of control and self-concept (Atli, 2017). Locus of control is one of the aspects that make up the personality of a person (Cakir, 2017). Locus of control is included in the cognitive aspects of personality that were pioneered by Rotter in 1966 (Algadheeb, 2015; Friedman and Schustack, 2008). Locus of control is the individual's perception of an event (success and failure) related to power control in a person, whether internal or external power control (Sari et al., 2013).

Locus of control has two dimensions, namely the locus of control internal and external locus of control (Arslan and Akin 2014; Zulkaida et al., 2007). Internal locus of control is an individual's belief that the effort and behavior will affect the events themselves and the lives that will be undertaken (Primary and Suharnan, 2014). While an external locus of control is an individual's belief that fate was determined by external factors (Arslan and Akin, 2014).

Individuals are expected to have an internal locus of control in itself because it will have a positive impact for the development of their lives and make their work more successful (Cakir, 2017; Manichander, 2014). In line with this, Friedman and Schustack (2008) mention individuals with an internal locus of control are more oriented to success for these people perceived that his actions would result in something positive. When linked with career maturity, internal locus of control makes the higher a person's career maturity (Widyastutiand Widyowati, 2015).

The second factor affecting the career maturity is the concept of self. The concept of self is the perception, observation, and assessment of themselves and in relation to other people in his life (Yusuf, 2002: 96). The concept itself is something that is essential for the students, because of the belief that every achievement is determined by the effort, skills, and abilities, the students will try to improve the abilities and skills into a career requirement (Primary and Suharnan, 2014). Putri (2016) expresses the concept of self as one of the foundations are very important to the success of life. Lawrence and Vimala (2013) added if a person feels good about himself and his ability, to predict a person's life will be successful.

The self-concept relates to typical job options and positions that will be someone's lap. The results showed that self-concept and career maturity developing in tandem with physical growth and cognitive development (Prasasti and Laksmiwati, 2017).

\section{Career Maturity}

Career Maturity is a term first used by Super in 1957 in career development theory (Coertse and Schepers, 2004). To reach one's career maturity should be able to accomplish the tasks of career development in accordance with the age and developmental stage of his career (Dodd et al., 2014).

Career maturity is the readiness of the individual to complete the task of career development at every stage of career development (Coertse and Schepers, 2004; Dodd et al., 2014; Janeiro, 2010). Career development tasks at every stage of career development can be seen in Table 1.

Table 1. Career Development Tasks at Each Stage Career Development

\begin{tabular}{|c|c|}
\hline $\begin{array}{c}\text { Stage Career } \\
\text { Development }\end{array}$ & Career Development Tasks \\
\hline $\begin{array}{l}\text { Growth } \\
(0-14 \text { years })\end{array}$ & Forming a mental picture of yourself in dealing with others \\
\hline Exploration & In general, explores the world of work and in particular about careers of \\
\hline
\end{tabular}




\begin{tabular}{|c|c|}
\hline (14-24 years) & interest \\
\hline $\begin{array}{l}\text { Formation }(24-44 \\
\text { years })\end{array}$ & $\begin{array}{l}\text { Strives to be established in the field of work-liked and right, then raise up to } \\
\text { fatigue or the highest position in the profession who acted }\end{array}$ \\
\hline $\begin{array}{l}\text { Maintenance (44-64 } \\
\text { years) }\end{array}$ & Maintaining what has been achieved \\
\hline $\begin{array}{l}\text { decline } \\
\text { (65 to death) }\end{array}$ & Starting escape from work and find another source of satisfaction \\
\hline
\end{tabular}

Teenagers included in the exploratory stage, so that career maturity in adolescence can be defined as how well people make a career choice and level of knowledge about educational and occupational choice (Coertse and Schepers, 2004). Maturity career has also included an important variable to be associated with the exploration phase (Brown and Lent, 2005; Coertse and Schepers, 2004). In line with this Atli (2017) says that the maturity of a career is a reflection of the individual in the choice of career readiness.

Dodd et al. (2014) mentions career maturity as an individual's ability to make the right career choice and are aware of what is required in making career decisions, as well as the extent to which individual choices are realistic and consistent over time. Career maturity is also known as the extent to which individuals acquire the knowledge and skills needed in the selection of realistic career and career decision in accordance with the task of career development in a stage career development. Atli (2016) adds the concept of career maturity as the ability to plan in the selection of a career, have an awareness of a career, and is responsible for selecting a career.

There are several factors that affect career maturity, Atli (2017) mentions that career maturity is influenced by the internal locus of control and self-concept.

\section{Locus Of Control Internal}

Locus of control is one of the most studied concepts in psychology (Manichander, 2014). Locus of control was first introduced by Julian Rotter in 1966 (Algadheeb, 2015) and is one of the aspects that make up the personality of a person (Cakir, 2017). Locus of control is included in the cognitive aspects of personality (Friedman and Schustack, 2008).

In terms of the term, the locus is the place, while the control is in control. So, literally, the locus of control is a control (Pratama and Suharnan, 2014). Locus of control describes how a person believes life as something that can be controlled or something that controls the lives (Manichander, 2014). Not much different, Cakir (2017) suggested that the locus of control is the level of confidence in the capabilities of the person in control of events in life.

Algadheeb (2015:20) defines the locus of control as follows:

"Is believing in the causes of results which have been achieved, as whether these results were achieved by actions and real performance levels and one's personal characteristics, or they were achieved only because of fate or luck or coincidence that one has nothing to do about it, and through such other things which are out of control and unpredictable"

Forte (2005) argues that the locus of control is a factor of success and failure of a person. Locus of control is also considered as individual perceptions about future events, whether caused by his own actions or external factors and strength beyond one's control (Algadheeb, 2015).

Locus of control has two dimensions Locus of Control Internal and External Locus of Control (Arslan and Akin 2014; Zulkaida et al., 2007). Arslan and Akin (2014: 34) explains the two dimensions are as follows:

"That people who believe that they make choices which affect their life circumstances are considered to have an internal locus of control, while people who believe their circumstances are controlled by external forces are described as having an external locus of control".

Algadheeb (2015) to add individuals who have an internal locus of control believe the failure or success in life due to their own ability and effort, while individual personality external locus of control believe the success or failure of external factors such as luck or a bad neighborhood.

The Locus of control internal and external locus of control have a highly significant difference (Sari, 2016). Manichander (2014) argues that individuals who have an internal locus of control have a sense of 
responsibility for what happened in his life, whereas individuals who have an external locus of control considers the circumstances or events is a matter of luck and no matter what they have done.

Cakir (2017) to add someone who has the internal locus of control have a sense of responsibility for the failures in life, they see success is something that is static, something waiting there, and can be achieved. Individuals who have an external locus of control has the opposite attitude, they assume that the events in his life are influenced by external factors such as the presence of an influential person, luck or coincidence, fate, and believe that something in the world is difficult to predict. Someone with an external locus of control did not connect between something that has been achieved with their own performance.

Individuals are expected to have an internal locus of control in itself because it will have a positive impact for the development of their lives and make their work more successful (Cakir, 2017; Manichander, 2014). In line with this, Friedman and Schustack (2008) mentions individuals with an internal locus of control is more oriented to success for these people perceived that his actions would result in something positive.

Widyastuti and Widyowati (2015) revealed that the internal locus of control makes the maturity of a person's career becomes higher. Some studies also show that there is a positive correlation between internal locus of control with the maturity of careers, including research by Pratama and Suhernan (2014), Widyastuti and Widyowati (2015), Nugraheni (2013), Ariyani (2014), and Zulkaida et al. (2007).

This is very different from the people who have an external locus of control,they have a tendency to laziness to try, assume that for any attempt will not guarantee success (Prestiana and Putri, 2013).

Someone who has an internal locus of control is deemed more successful in the field of employment (Manichander, 2014). Someone who has an internal locus of control has a high achievement motivation and see success is something that is static, something waiting there, and can be reached (Cakir, 2017).

Career maturity in adolescents is defined as how well people make a career choice and level of knowledge about education and job selection (Coertse and Schepers, 2004). Someone who has an internal locus of control in the selection of her career empowering potential in order to obtain the best result in the career decision-making process. Individuals who have an internal locus of control will actively seek information, this shows that there is a link between internal locus of control with the maturity of the career so as to achieve the career maturity required internal locus of control within the individual (Ariyani, 2014)

Someone who has an internal locus of control has confidence that something is happening in their lives are the results of operations and the behavior itself (Pranata and Suharnan, 2014). The same thing was stated by Srimulyani (2013) that a person whose internal locus of control to see the success or failure in life depends on yourself. They have a sense of responsibility for success or failure in life (Cakir, 2017). Ariyani (2014) a person whose internal locus of control believe the skills (skills), ability(ability), and business (Efforts)further determine the achievement in their lives, including the achievement of his career.

Characteristics of a person if they have the internal locus of control is as follows (Aji et al., 2010; Nugraheni, 2013; Pratama and Suharnan, 2014; Srimulyani, 2013):

control, that person has the belief that events in life are the result of internal factors,

independent, that someone in his attempt to achieve a goal or outcome, believe in the ability and skill itself,

responsibility, ie one has to admit everything as a result of the attitude or behavior, as well as trying to fix it in order to achieve better results again,

expectancy, ie someone has a subjective judgment or the conviction that positive consequences will be obtained in certain situations as a rewarding behavior.

\section{Self Concept}

The self-concept is the most important element in the process of human growth and development (Lawrence and Vimala, 2013). In general, the self-concept described as one's perception of oneself. These perceptions are formed through experience with the environment (Rinn et al., 2013; Whitley et al., 2014). Agustiani (2006) define self-concept as an idea held by individuals against him that were formed through the experiences gained from interaction with the environment.

The self-concept is the perception, observation, and assessment of themselves and in relation to other people in his life (Yusuf, 2002: 96). In line with this Agarwal et al. (2013) define the self-concept as one's perception of oneself that is formed from the experience and the environment, where a person plays an important role. 
The self-concept is something that is essential for the students, because of the belief that every achievement is determined by the effort, skills, and abilities, the students will try to improve the abilities and skills into a career requirement (Pratama and Suhernan, 2014). Putri (2016) expresses the self-concept as one of the foundations are very important to the success of life. Lawrence and Vimala (2013) added if a person feels good about himself and his ability, to predict a person's life will be successful.

The self-concept relates to typical job options and positions that will be someone's lap. The results showed that self-concept and career maturity developing in tandem with physical growth and cognitive development (Prasasti and Laksmiwati, 2017).

\section{Conclusion}

The period of senior high school is characterized by several key characteristics, such as making choices and prepare for careers match their interests and abilities. High school students are faced with the choice to go to college or work after completing education. The reality of high school students who have completed their education could not determine the direction of career planning.

Individuals who are not ready and is not appropriate in the career election caused by the low career maturity. The phenomenon suggests that high school students have a career maturity that can pick and choose the appropriate career direction because the career maturity is important in the choice of the career.

The career maturity of individual readiness to complete the task of career development at every stage of career development. Career maturity is influenced by several factors, among others locus of control and selfconcept. Locus of control is the individual's perception of an event (success and failure) related to power control in a person, whether internal or external control power. Locus of control has two dimensions, namely the locus of control internal and external locus of control. Internal locus of control is an individual's belief that the effort and behavior will affect the events themselves and the lives that will be undertaken. While an external locus of control is an individual's belief that its fate is determined by outside factors.

Individuals are expected to have an internal locus of control because it will positively impact the development of their lives and make their work more successful. Someone who has the internal locus of control makes the higher a person's career maturity. Very different from the people who have an external locus of control inside, they have a belief that fate was determined by an influential person, luck or coincidence, fate, and the belief that the world is too complicated to predict. They almost do not establish a relationship between the results they achieve by their own actions. There is a tendency to try to lazy behavior, they think that no matter how much effort will not guarantee success.

The second factor affecting the career maturity is the concept of self. The concept of self is the perception, observation, and assessment of themselves and in relation to others in his life. The concept itself is something that is essential for the students, because of the belief that every achievement is determined by the effort, skills, and abilities, the students will try to improve the abilities and skills into a career requirement. The concept itself is one of the foundations are very important to the success of life. If someone feels good about himself and his ability, to predict a person's life will be successful. The self-concept relates to typical job options and positions that will be someone's lap. The results showed that self-concept and career maturity developing in tandem with physical growth and cognitive development.

\section{References}

Afdal, A., Suya, M., Syamsu, S., \& Uman, U. (2014). Bimbingan Karir Kolaboratif dalam Pemantapan Perencanaan Karir Siswa SMA. Jurnal Konseling dan Pendidikan, 2(3), 1-7.

Afdal, A., Elviana, E., \& Alizamar, A. (2017). The Role of Counselors in the Development of Career Planning for Youth Inmates. GUIDENA: Jurnal Ilmu Pendidikan, Psikologi, Bimbingan dan Konseling, 7(2).

Afdal, A. (2015). Kolaboratif: Kerangka Kerja Konselor Masa Depan. Jurnal Konseling dan Pendidikan, 3(2), 17.

Agarwal, Shivani. et al. (2013). "Relationship Between Self-Concept and Academic Achievement in 17-19 Years Old Students". International Journal of Physiology, 1 (2): 125-129.

Agustiani, Hendrianti. (2006). Psikologi Perkembangan: Pendekatan Ekologi Kaitannya dengan Konsep Diri dan Penyesuaian Diri pada Remaja. Bandung: Refika Aditama. 
Aji, Rahmanto. et al. (2010). "Hubungan antara Locus of Control Internal dengan Kematangan Karier pada Siswa Kelas XII SMK N 4 Purworejo". Unpublished Dissertation. Semarang: Fakultas Psikologi Universitas Diponegoro.

Algadheeb, Noura A. (2015). "Professional/Career Orientation, Awareness, and Their Relationship to Locus Of Control". Journal of College Teaching and Learning, 12 (1): 13-38.

Ardi, Z. (2014). Cita-cita Perkerjaan dan Pilihan Peminatan Siswa Sekolah Menengah Atas Negeri di Sumatera Barat.

Ardi, Z., \& Yendi, F. M. (2017). Students Attitude Towards LGBTQ; the Future Counselor Challenges. Jurnal Konseling dan Pendidikan, 5(2), 74-79.

Ardi, Z., \& Sukmawati, I. (2018). Social Media and the Quality of Subjective Well-Being; Counseling Perspective in Digital Era.

Ardi, Z., Ibrahim, Y., \& Said, A. (2012). Capaian Tugas Perkembangan Sosial Siswa dengan Kelompok Teman Sebaya dan Implikasinya terhadap Program Pelayanan Bimbingan dan Konseling. Konselor, 1(2).

Ariyani, Eli. (2014). "Pengaruh Internal Locus of Control terhadap Kematangan Karier Siswa Madrasah Aliyah Negeri 2 Samarinda". Motivasi, 2 (2): 1-38.

Arslan, Serhat and Akin, Ahmet. (2014). "Metacognition: As a Predictor of One's Academic Locus of Control". Educational Sciences : Theory and Practice, 14(1) : 33-39

Athiyah, Ibnu. et al. (2014). "Career Information Service Model Multimedia-Assisted for Increasing Students Career Maturity". Jurnal Bimbingan Konseling, 3 (1): 16-21.

Atli, Abdullah. (2016). "The Effects of Trait-factor Theory Based Career Counseling Sessions on the Levels of Career Maturity and Indecision of High School Students". Universal Journal of Educational Research, 4(8): 1837-1847.

Atli, Abdullah. (2017). "Five $\square$ Factor Personality Traits as Predictor of Career Maturity". Eurasian Journal of Educational Research, 68 (2017): 151-165.

Atmaja, Twi Tandar. (2014). "Upaya Meningkatkan Perencanaan Karier Siswa Melalui Bimbingan Karier dengan Penggunaan Media Modul”. Psikopedagogia, 3 (2): 58-68.

Bardick, A.D. et al. (2006). "Junior High School Students' Career Plans for the Future". Value in Health, 32(3): 218-223.

Brown, Steven D and Lent, Robert W. (2005). Career Development And Counseling: Putting Theory and Research to Work. New Jersey: John Wiley \& Sons, Inc.

Cakir, Mustafa. (2017). "Investigating Prospective Teachers' Perceived Problem-solving Abilities in Relation to Gender, Major, Place Lived, and Locus of Control". Universal Journal of Educational Research, 5(6): 1030-1038.

Coertse and Schepers. (2004). "Some Personality and Cognitive Correlates of Career Maturity". Journal of Industrial Psychology, 30 (2): 56-73.

Daharnis, D., \& Ardi, Z. (2016). The Compatibility Student Choice of University Majoring; a Preliminary Studies. GUIDENA: Jurnal Ilmu Pendidikan, Psikologi, Bimbingan dan Konseling, 6(1), 101-109.

Daharnis, D., Ardi, Z., \& Ifdil, I. (2018). The Improved of Counselor Competencies through Scientific Article Writing Training Using Digital Citation Application. Jurnal Konseling dan Pendidikan, 6(1), 8.

Dodd, Courtney F. et al. (2014). "The Career Maturity of 4-H Healthy Lifestyles Program Participants". Journal of Youth Development, 9 (3): 1-13.

Forte, Almerinda. (2005). " Locus of Control and the Moral Reasoning of Managers". Journal of Business Ethics, 58: 65-77. 
Friedman, Howard S dan Schustack, Miriam W. (2008). Kepribadian: Teori Klasik dan Riset Modern Edisi Ketiga. Jakarta: Erlangga.

Gaylor, Lisa and Nicol, Jennifer J. (2016). "Experiential High School Career Education, Self-Efficacy, and Motivation". Canadian Journal of Education, 39 (2): 1-24.

Gladding, Samuel T. (2012). Konseling: Profesi yang Menyeluruh. Jakarta: Indeks.

Hidayati, N. W. (2016). "Pengaruh Layanan Informasi Studi Lanjut Terhadap Perencanaan Karier Siswa”. Edukasi: Jurnal Pendidikan, 12(1): 94-101.

ILO. (2011). Panduan Pelayanan Bimbingan Karier. Jakarta: ABKIN.

Janeiro, Isabel Nunes. (2010). "Motivational Dynamics in the Development of Career Attitudes Among Adolescents". Journal of Vocational Behavior, 76 (2010): 170-177.

Krjogja.com. (2017). "7,03 Juta Pengangguran didominasi Lulusan SMA". (http://krjogja.com/web/news/read/26832/7_03_Juta_Pengangguran_Didominasi_Lulusan_S MA, accessed 10 Juny 2017).

Lawer, D. (2015). "Factors that Inform Students ' Choice of Study and Career". Journal of Education and Practice, 6(27), 43-50.

Lawrence, A.S and Vimala, A. (2013). "Self-Concept and Achievement Motivation of High School Students". Conflux Journal of Education, 1 (1): 141-146.

Leksana, Dinar Mahdalena. (2015). "Pengembangan Modul Bimbingan Karier Berbasis Multimedia Interaktif untuk Meningkatkan Kematangan Karier Siswa”. Jurnal Akademika, 9 (2): 290-298.

Manichander, T. (2014). "Locus of Control and Performance: Widening Applicabilities". Indian Journal of Research, 3 (2): 84-86.

Novakovic, Alexandra and Fouad, Nadya A. (2012). "Background, Personal, and Environmental Influences on the Career Planning of Adolescent Girls". Journal of Career Development, 40(3) 223-244.

Nugraheni, Intan. (2013). "Hubungan Antara Pusat Kendali Internal dengan Kematangan Karier pada Siswa Kelas XII SMK Kristen 1 Klaten”. EMPATHY Jurnal Fakultas Psikologi, 2 (1): 1-22.

Prasasti and Laksmiwati. (2017). "Perbedaan Kematangan Karier Ditinjau Dari Konsep Diri dan Gender Pada Siswa Kelas X Di SMA PGRI 1 Kota Mojokerto”. Jurnal Psikologi Pendidikan, 4 (1): 1-7.

Pratama, Beny Dwi and Suhernan. (2014). "Hubungan Antara Konsep Diri dan Internal Locus of Control dengan Kematangan Karier Siswa SMA”. Jurnal Psikologi Indonesia, 3 (3): 213-222.

Prestiana, N. D. I., and Putri, T. X. A. (2013). "Internal Locus of Control dan Job Insecurity terhadap Burnout pada Guru Honorer Sekolah Dasar Negeri di Bekasi Selatan”. SOUL, 6(1): 57-76.

Putri, Sefni Rama. (2016). "Kontribusi Tingkat Penerimaan oleh Teman Sebaya dan Konsep Diri terhadap Motivasi Belajar Siswa di SMK Nusatama Padang serta Implikasinya dalam Program Bimbingan dan Konseling”. Unpublished Dissertation. Padang: Fakultas Ilmu Pendidikan Universitas Negeri Padang.

Restu, Y., Yusri, Y., \& Ardi, Z. (2013). Studi Tentang Perilaku Agresif Siswa di Sekolah. Konselor, 2(1).

Rinn, Anne. N. (2013). "Family Context Predictors of Math Self-Concept Among Undergraduate STEM Majors: An Analysis Of Gender Differences". Journal of the Scholarship of Teaching and Learning, 13 (2): 116 132.

Rogers and Creed. (2011). "A Longitudinal Examination of Adolescent Career Planning and Exploration Using A Social Cognitive Career Theory Framework". Jurnal of Adolescence, 34: 163-172.

Sari, Ayu Permata. (2016). "Self Regulated Learning dan Locus of Control Siswa Ditinjau dari Jenis Kelamin dan Latar Belakang Budaya. Unpublished Dissertation. Padang: Program Studi S2 BK UNP. 
Sari, Intan. et al. (2013). "Locus of Control dan Perilaku Menyontek serta Implikasinya terhadap Bimbingan dan Konseling (Studi pada Siswa Sekolah Menengah Atas Padang Ganting)". Jurnal Ilmiah Konseling: 2 (1): 267-272.

Srimulyani, V. Agustini. (2013). "Analisis Pengaruh Kecerdasan Adversitas, Internal Locus of Control, Kematangan Karier terhadap Intensi Berwirausaha pada Mahasiswa Bekerja". Widya Warta, 2 (1): 96110.

Sterner, W. R. (2012). "Integrating Existentialism and Super 's Life-Span, Life-Space Approach". Existentialism and Career Counseling, 60 (June), 152-162.

Syakir, Muhammad. et al. (2016). "The Model of ICT-Based Career Information Services and Decision-Making Ability of Learners". International Journal of Environmental and Science Education, 11 (13): 59695979 .

Ting, S.R. et al. (2012). "A Preliminary Study of Career Education in Middle School". Journal of Career and Technical Education, 27 (2): 84-97.

Usinger, Janet and Smith, Marylin. (2010). "Career Development in the Context of Self-Construction During Adolescence". Journal of Career and Technical Education, 76: 580-591.

Walgito, Bimo. (2010). Bimbingan + Konseling (Studi \& Karier). Yogyakarta: Andi.

Whitley, Jessica. et al. (2014). "A Comparison of Aboriginal and Non-Aboriginal Students on the Inter-Related Dimensions of Self-concept, Strengths and Achievement”. Brock Education, 23(2): 24-46.

Widyastuti, Ninik and Widyowati, Arini. (2015). "Hubungan Antara Locus of Control Internal dengan Kematangan Karier Pada Siswa SMK N 1 Bantul”. HUMANITAS (Jurnal Psikologi Indonesia), 12(2): 8289.

Yanti, S., Erlamsyah, E., Zikra, Z., \& Ardi, Z. (2013). Hubungan antara Kecemasan dalam Belajar dengan Motivasi Belajar Siswa. Konselor, 2(1).

Yusuf, A. Muri. (2002). Kiat Sukses dalam Karier. Padang: Ghalia Indonesia.

Zulkaida, Anita. et al. (2007). "Pengaruh Locus of Control dan Efikasi Diri terhadap Kematangan Karier Siswa Sekola Menengah Atas (SMA)". Paper presented in Proceeding PESAT (Psikologi, Ekonomi, Sosial, dan Sipil), Gunadarma, Bogor, 21-22 August. 